\title{
Detection of an aortoenteric fistula in a patient with intermittent bleeding
}

Bülent Ödemiş, Ömer Başar ${ }^{\star}$, İbrahim Ertuğrul, Mehmet İbiş, İlhami Yüksel, Engin Uçar and Kemal Arda Nature Clinical Practice Gastroenterology \& Hepatology (2008) 5: 226-230 [doi:10.1038/ncpgasthep1075]

\section{Erratum}

In the April 2008 issue of Nature Clinical Practice Gastroenterology \& Hepatology, the published online date for the Case Study by Ödemiş et al. was incorrect. The article was published online on 11 March 2008. doi:10.1038/ncpgasthep1148 